\title{
ROLE OF HEPATITIS B AND HEPATITS C VIRUS COINFECTION IN TB DEVELOPMENT
}

\author{
Pudji Lestari, Ivan Rahmatullah, Dwi Susanti \\ Department of Public Health and Preventive Medicine \\ Faculty of Medicine, Universitas Airlangga
}

\begin{abstract}
ABSTRAK
Perkembangan penyakit Tuberkulosis (TB) pada tiap individu berbeda. Peran penyakit koinveksi seperti HIV cukup significant namun peran penyakit lain seperti Hepatitis $B$ dan Hepatitis $B$ belum banyak diketuahui. Oleh karena itu, penelitian ini bermaksud untuk menggambarkan peran koinfeksi virus hepatitis dalam perkembangan TB. Metode penelitian adalah observasional - case control dengan dua. Kelompok pertama adalah penderita TB dan kelompok kedua adalah kelompok control. Data yang dikumpulkan meliputi kondisi TB, apakah laten atau manifest, dan riwayat infeksi Hepatitis B dan C. Penelitian ini berhasil melibatkan total 32 responden pada masing - masing kelompok. Pada kelompok kasus, jumlah responden laki-laki sebanyak 19 orang dan perempuan sebanyak 13 orang. Sementara pada kelompok control, jumlah responden laki-laki sebanyak 10 orang dan perempuan sebanyak 22 orang. Pada kelompok kasus, didapatkan 20 orang responden positif dengan riwayat hepatitis B. Sedangkan pada kelompok kontrol didapatkan 12 orang responden positif. Hasil perhitungan dengan chi-square menunjukkan adanya perbedaan yang signifikan antara kedua kelompok $(P=0.0455$ dan $\alpha=0.05)$ dengan odd ratio $p=0.479$. Sementara itu, penelitian ini mendapati hanya satu orang responden yang positif riwayat koinfeksi $C$ dan dua orang pada kelompok kontrol. Uji beda pada dua kelompok menunjukkan hasil yang tidak signfikan $(P=1$ dan $\alpha=0.05)$. Penelitian ini menunjukkan bahwa penderita tuberkulosis lebih mungkin memiliki riwayat koinfeksi virus hepatitis $B 2,7$ kali dibandingkan kelompok kontrol yang terinfeksi Hepatitis $B$ namun tidak sakit Tuberkulosis. Sehingga, kemungkinan koinfeksi virus hepatitis B berperan pada manifestasi penyakit tuberculosis namun tidak dengan riwayat koinfeksi hepatitis C. (FMI 2016;52:19-23)
\end{abstract}

Kata kunci: hepatitis B, hepatitis C, koinfeksi, tuberkulosis

\begin{abstract}
Tuberculosis developed differently in each individual. The role of HIV in the disease development is widely known unlike the role of Hepatitis $B$ and Hepatitis $C$ infection. Therefore, this study is aimed at to describe the role of those co-infections in the TB development. The study employed observational - case control design with two groups, case and control group. Data collection include TB condition, whether latent or manifest, and history of Hepatitis B and Hepatitis C co-infection. The study successfully recruited the total of 32 respondents in each group. At the case group, the number of male and respondent is 19 and 13 . Meanwhile, at the control group the number male respondent is 10 and the female respondent is 22. The study found that 20 and 12 respondents were positive Hepatitis $B$ at the case and the control group. Chi-square test resulted significant different between two groups $(P=0.0455$ and $\alpha=0.05)$ with odd ratio $p=0.479$. Meanwhile, the study only tested one respondent with positive Hepatitis $C$ at case group and one at control group. Comparison analysis found no significant different between groups $(P=1$ and $\alpha=0.05)$. This study reveals that TB patients are more likely to have history of Hepatitis $B 2.7$ times than those at the control group with the same infection but without TB development. Therefore, the possibility of Hepatitis B co-infection has role in the TB manifestation, but not for Hepatitis C co-infection. (FMI 2016;52:19-23)
\end{abstract}

Keywords: hepatitis B, hepatitis C, coinfection, tuberculosis

Correspondence: Pudji Lestari, Department of Public Health and Preventive Medicine, Faculty of Medicine, Universitas Airlangga

\section{INTRODUCTION}

Indonesia is included in high-burden countries for Tuber-culosis (TB). The number of new cases in 2012 amounted to 202,319 cases. The threat of such magnitude of TB cases is the drop in productivity, because the ratio of illness between males and females was $1: 1.5$ and nearly $90 \%$ of the patients aged over 15 years (WHO 2013). Report of Basic Health Research (Riskesdas) 2010, found that the point prevalence of TB (at least one slide) reached 704/100,000, which many higher than the WHO global report of 244/100,000 (MOH 2011). The development of TB disease in each individual is different, whether becomes latent or manifest. However, how cases of infection becomes latent or manifest, remains unclear. More than $90 \%$ of cases remain as latent cases, while the rest are developing into disease. Thus there is a need to find other approaches to the identification of group with a risk of illness. Further efforts for more effective 
prevention of tuberculosis can therefore be done (Soemantri et al 2007).

Infection of Human Immunodeficiency Virus (HIV) and the development of Acquired Immune Syndrome Deficiency (AIDS) provide new insights into the course of the tuberculosis disease. The HIV virus is known to allow the bacteria Mycobacterium tuberculosis, by creating ideal conditions through the suppression of CD4 cells. With the existence of HIV it is known that there is an interaction between viral infection and latent infection of bacteria. The evidence suggests, someone who recovered from TB, TB does not become free, even having higher risk of illness than people who have latent infection. It shows that TB is a disease of opportunism. Indonesia is endemic TB region, the number of cases of latent estimated doubled from the number of TB patients. It is important to identify the factors that play a role in the development of TB that has become a disease as the health concern of TB is its form as a disease, not a latent $\mathrm{TB}$.

Nagelkerke filed a 'double hit' theory to explain the role of co-infection diseases in the development of TB disease. This theory suspect virus coinfection that would cause someone who is already infected develop the disease, and vice versa when it is infected by this virus and then infected with Mycobacterium tuberculosis it will manifest. This virus has characteristics such as sexually transmitted or blood through other body fluids. So people with promisquity (free sex) are more susceptible to infection with this virus (Nagelkerke 2012).

Hepatitis B and C is a viral infection which is also present in high promisquity groups (eg sex workers and homosexual) and also more common among inject-ing drug abusers. Hepatitis viruses are also threatening infections in transfusion recipients and users of the dialysis machine. Infection with this virus is also a chronic case of the manifestation that will appear 10-20 years later. Thus these viruses are ideal candidates for co-infected with TB. Therefore, this study aims to identify the description of viral hepatitis coinfection role in the development of TB.

\section{MATERIALS AND METHODS}

This study was an observational case control study with two groups, the case group and the control group. The case group was adult patients diagnosed with sputum smear-positive are undergoing treatment at a government hospital in Surabaya, while the control group were health workers or family members of patients. The number of each group was 32 adults. The research was conducted in the period from August to October 2014.
Studied variables included the condition TB, whether latent or manifest, and a history of Hepatitis B and C.

$\mathrm{xxx}$

The study began with a feasibility test of ethics which was done by Bioethics Unit, Faculty of Medicine. After eligibility certificate of conduct was established, the researchers proposed permit to conduct research in the government hospital, Surabaya. Once the permission was obtained, the researchers encountered a group of cases that TB patients who already diagnosis of smear positive $\mathrm{TB}$ services at the facility. Willingness to undergo serological examination requested form which preceded availability information for standard procedures concent. Meanwhile, a control group matched by age and sex of the patient, found in TB care (family) or in the homes of people (contacts). They requested a willingness to take blood for examination and serological Mantoux test in the consent form. If the observations foun thath the household contacts become ill with $\mathrm{TB}$, he/she will be removed from the control group.

Procedures of blood collection from all respondents was that as much as $10 \mathrm{cc}$ of blood to be divided into $4 \mathrm{cc}$ of whole blood + EDTA for examination hematology blood, in control group: Mantoux test was checked, while all respondents checked serum or plasma for ELISA against anti-HBV and anti-HCV. Tests done include: Mantoux test, serology examination of antiHBV and anti-HCV by ELISA, and Character-istics of respondents: age, their illness (diabetes, HIV, and a history of allergies) using a questionnaire.

The data collected will be described descriptively and presented in the table of distribution. Then, an analysis using univariate test for each of the risk of co-infection. Statistical test is done using fisher, chi-square, t-test, and odds ratios. Statistical significance set at $p \leq 0.05$. Data distribution and analysis using appropriate computer software.

\section{RESULTS}

This study was able to recruit a number of each person in the group of 32 adults with diagnosed TB patients' sputum smear-positive and control groups. Of the 32 people in the case group, the number of male respondents as many as 19 people and 13 women among as seen in Table 1. Meanwhile, for the control group the number of male respondents was 10 women and 22 people, as seen in table 1.

In the study also found the average age of the respondents in the case group was 40 years with a standard deviation of 11.5 with the oldest age of 
respondents was 62 years, while the youngest was 20 years old. In the control group, the average age is 40.9 and the standard deviation of 13.1 with the oldest aged 65 and the youngest 20 years old. Test performed depending on the age of the two groups with $t$ test showed $\mathrm{P}=0.716$ and $\alpha=0.05$ which means there is no significant difference between the 2 groups. As seen in Table 2

Table 1. Respondents' gender

\begin{tabular}{lcccc}
\hline & \multicolumn{2}{c}{ Case Group } & \multicolumn{2}{c}{ Control Group } \\
\cline { 2 - 5 } Male & Freq. & $\%$ & Freq. & $\%$ \\
Female & 19 & 59.4 & 10 & 31.3 \\
\hline Total & 13 & 40.6 & 22 & 68.8 \\
\hline Comparative test with Chi square $; \mathrm{P}=0.077794 ; \alpha=0.05 ;$ \\
No significant difference between two groups
\end{tabular}

Table 2. Age of respondents

\begin{tabular}{lcc}
\hline Groups & Case (32 persons) & Control (32 persons) \\
\hline Mean and SD & $40.00+/-11.5$ & $40.9+/-13.1$ \\
Maximum & 62 & 65 \\
Minimum & 20 & 20 \\
\hline Comparative test with t test ; $\mathrm{P}=0.716 ; \alpha=0.05 ;$ No significant \\
difference between two groups
\end{tabular}

Test for history of hepatitis B virus in this study in the case group, obtained 20 respondents 12 respondents positive and negative. While the control group got 12 respondents 20 respondents positive and negative. Different test was also carried out between the two groups. The result of the calculation with chi-square shows the results; $\mathrm{P}=0.0455$ and $\alpha=0.05$ which means there is a significant difference between the two groups with odd ratio $\mathrm{p}=0479$. As seen in Table 3 .

Table 3. History of co-infection with hepatitis B virus

\begin{tabular}{lcccc}
\hline & \multicolumn{2}{c}{ Case } & \multicolumn{2}{c}{ Control } \\
\cline { 2 - 5 } & Freq. & $\%$ & Freq. & $\%$ \\
\hline Hepatitis B Antibody positive & 20 & 62.5 & 12 & 37.5 \\
Hepatitis B Antibody negative & 12 & 37.5 & 20 & 62.5 \\
\hline Total & 32 & 100 & 32 & 100 \\
\hline Comparative test with chi-square; $\mathrm{P}=0.0455 ; \alpha=0.05$ & ; Two groups \\
shows significant difference; Odd ratio $\mathrm{P}=0.0479$ & & \\
\hline
\end{tabular}

Test for history of hepatitis $\mathrm{C}$ virus in this study, only one person respondent positive in case group. Meanwhile, 31 other responded negatively. In the control group, there were two people with a positive result and 30 people with a negative result. Different test was also carried out between the two groups also performed. Fisher exact test results show results; $P=1$ and $p=0.05$ which means there is no significant difference between the 2 groups. As seen in Table 4.
Table 4. History of hepatitis $\mathrm{C}$ virus coinfection

\begin{tabular}{lcccc}
\hline & \multicolumn{2}{c}{ Case } & \multicolumn{2}{c}{ Control } \\
\cline { 2 - 5 } & Freq. & $\%$ & Freq. & $\%$ \\
\hline Hepatitis C Antibody positive & 1 & 96.8 & 2 & 93.8 \\
Hepatitis C Antibody negative & 31 & 3.1 & 30 & 6.3 \\
\hline Total & 32 & 100 & 32 & 100 \\
\hline $\begin{array}{l}\text { Comparative test with Fisher exacts test } ; \mathrm{P}=1 ; \alpha=0.05 ; \text { No } \\
\text { significant difference between two groups }\end{array}$ & & \\
\hline
\end{tabular}

\section{DISCUSSION}

The results of this study showed that there was no significant difference between the control group and the case group in terms of age and gender. Thus, these two factors can be balanced, and has been controlled in the hope of another variable results in both groups were compared.

In this study, we used the criterion of control is family tuberculosis with sputum positive stay at home for two consecutive years, according to a study Setiawati et al (2011) and Lestari et al (2011), Mantoux positive and quantitation of Interferon (IGRA) actually showed only partial of the infected group (sensitivity $60 \%$ ).

This study found quite a lot of people with TB also have been exposed to hepatitis infection (especially hepatitis B), OR in this study of 2.7. This means that patients are 2.7 times more likely to have a history of hepatitis B infection, rather than control. This finding is consistent with research findings in China at risk groups of drug users who find an odd ratio was higher in coinfection Hepatitis virus (Zhang et al 2013). Another study, still in China, also found the risk of clinical manifestations of tuberculosis increased in the group with oncogenic HPV infection (Graubard et al 2011). These facts support the hypothesis that virus infection associated with disease manifestations in tuberculosis.

This study found only one person tuberculosis sufferers who also have been exposed to hepatitis C. Meanwhile, the control group did not obtain similar fact. Although the results showed no significant between the role of hepatitis C coinfection TB circuitry, but this study shows a similar trend to the importance of analyzing the role of co-infection in TB patients. The study in China found that the risk of clinical manifestations of tuberculosis increased in the group with oncogenic HPV infection (Graubard et al 2011). These facts support the hypothesis that virus infection associated with disease manifestations in tuberculosis.

Elucidation of the role of coinfection against tuberculosis disease manifestations may be obtained from meta-analysis of Dextran paper written by Pustylnikov 
et al. Uptake of hepatitis $\mathrm{C}$ virus and Mycobacterium tuberculosis share in dendritic cell receptor and mannose receptor same (Pustylnikov 2014). Regulatory $\mathrm{T}$ cell helper 1 (Th1) and T helper cell 2 starts here. Can speculate that a history of hepatitis virus uptake interrupt/macrophage response to change in the face of Mycobacterium tuberculosis.

Thus, the above facts support the hypothesis that not only HIV but also other viruses are transmitted through body fluids and sex, play a role in the manifestation of tuberculosis. This is in line with the opinion of Nagelkerke (2012) who found similarities disrtibusi age and sex of tuberculosis and sexually transmitted diseases. As an opportunistic disease, tuberculosis appears when there is interference with the balance between Th1 and Th2.

As the implications of the above, then when the results of liver function tests as monitoring treatment showed an increase, then the interpretation should be expanded not only as a result of drug toxicity, but also the possibility of an active viral hepatitis infection should also be explored. Mo et al study found that in the group of multi-infection with HIV/TB/HBV and HIV/TB/ $\mathrm{HCV}$ incidence of abnormal liver function were significantly higher (OR 5.525). The study also showed that mortality was higher in multi infection (19.7\%) (Mo et al 2014). Thus in the treatment of tuberculosis patients with abnormal liver function, requires a serious follow-up.

The limitation in this study is that the study is just a history of never infected with hepatitis B and hepatitis $\mathrm{C}$, by measuring antibodies patient/control of hepatitis $\mathrm{B}$ (anti- HBV and hepatitis $\mathrm{C}$ (anti-HCV). It is realized also the limitations of these two antibodies in detection history of hepatitis due to the emergence later than suppose is Ig M anti-HBc, but the period of orbit in the blood longer, although not all anti-HBc. thus, this study did not measure whether there is an antigen hepatitis to be active, was also negativity antibody result does not mean the absence of a history of infection.

\section{CONCLUSION}

Tuberculosis sufferers were more likely to have a history of hepatitis B virus 2.7 times than that of infected control but not sick. Coinfection of hepatitis $\mathrm{C}$ virus possibly does not play a role in the manifestatoin of tuberculosis, since Indonesia is an endemic area of hepatitis $\mathrm{B}$, instead of hepatitis $\mathrm{C}$, as individuals with hepatitis $\mathrm{C}$ infection history are minority. However, it remains necessary to have deep thought about the handling of tuberculosis. As long as the tuberculosis bacteria is latent, body response is appropriate, not shifting towards tissue damage, the infection of the bacteria will not pose any problems. When this virus coinfection plays a role in the emergence of disease manifestations, it is necessary to think about this coinfection prevention which would be beneficial for the prevention of tuberculosis. In this case the possible prevention of hepatitis transmission is through blood products or sexual intercourse. In terms of management of the treatment of tuberculosis, screening liver function tests or hepatitis antibody-antigen test may need to be considered in preventing more severe hepatotoxicity and death.

\section{REFERENCES}

Graubard SYH, Chen F, Barrett CJ, Qiao YL, Forman MR (2011). Tuberculosis and oncogenic HPV: potential co-infections in women at high-risk of cervical cancer in rural China. Asian Pacific Journal of Cancer Prevention 12, 1409-1415

Lestari P, Sustini F, Endaryanto A, Asih R (2011). Home humidity increased risk of tuberculosis in children living with adult active tuberculosis cases. Universa medicina 30, 138-145

Ministry of Health Republic of Indonesia (2010). Report on Result of National Basic Health Research (RISKESDAS 2010), Jakarta, Departemen Kesehatan Republik Indonesia

Mo P, Zhu Q, Teter C, Yang R, Den L, Yan Y, Chen J, Zeng J, ui XE (2014). Prevalence, drug-induced hepatotoxicity, and mortality among patients multiinfected with HIV, tuberculosis, and hepatitis virus. Int J Infect Dis 28, 95-100

Nagelkerke N (2012). Courtesans and consumption, how sexually transmitted infection drive tuberkulosis epidemics. Eburon, Delft Netherlands.

Pustylnikov S, Sagar D, Jain P, Khan Z (2014). Targeting the C-type lectins-mediated host-pathogen interaction with dextran. J Pharm Pharm Sci 17, 371392

Setiawati L, Endaryanto A, Kusumadewi A, Lestari P (2011). Effect of BCG vaccination and nontuberculous mycrobacterium infection on interferon gamma specific assay and a tuberculin ski test amonf children with a tuberculosis contact in Surabaya, Indonesia. Southeast Asian J Trop Med Public Health 42, 1460-1468

Soemantri S, Senewe FP, Tjandrarini DH, Day R, Basri C, Manissero D, Mehta F, Dye C (2007). Three-fold reduction in the prevalence of tuberculosis over 25 years in Indonesia. The International Journal of Tuberculosis and Lung Disease 11, 398-404

WHO (2013). TB country profile 2013. Available from https://extranet.who.int/sree/Reports?op=Replet\&nam 
$\mathrm{e}=\% 2 \mathrm{FWHO} H \mathrm{HQ}$ Reports$\% 2 \mathrm{FG} 2 \% 2 \mathrm{FPROD} \% 2 \mathrm{FEX}$ T\%2FTBCountryProfile \&ISO2=ID\&LAN=EN\&outty pe $=$ html. Accessed November 2, 2013

Zhang L, Zhang D, Chen W, Zou X, Ling L (2013). High prevalence of HIV, HCV and tuberkulosis and associated risk behaviours among new entrants of methadone maintenance treatment clinics in Guangdong Province, China. PLoS One 8, e76931 